\title{
Psychological Data Information Specialization Services in Increasing Student's Self Understanding
}

\author{
Ni Ketut Suarni \\ Guidance and Counseling \\ Department \\ Universitas Pendidikan Ganesha \\ Bali, Indonesia \\ niketut.suarni@undiksha.ac.id
}

\author{
I Ketut Dharsana \\ Guidance and Counseling \\ Department \\ Universitas Pendidikan Ganesha \\ Bali, Indonesia \\ iketut.dharsana@undiksha.ac.id
}

\author{
Gede Nugraha Sudarsana \\ Guidance and Counseling \\ Department \\ Universitas Pendidikan Ganesha \\ Bali, Indonesia \\ nugraha.sudarsana@undiksha.ac.id
}

\begin{abstract}
This study aims to determine the effect of psychological data-based specialization information services in increasing student's self-understanding of the choice of majors through Lesson Study for Public Middle School students in Singaraja City. This type of research is an experimental study with the Nonequivalent Pre-posttest Control Group Design research design that is research that uses intact groups. The sampling technique in this study used a random sampling technique by lottery. The data analysis used in this study is an independent (uncorrelated) sample t-test analysis. Based on the results of t-count analysis obtained at 3.218 and t-table amounting to 1977 . When compared the value of $\mathrm{t}$-count with $\mathrm{t}$-table, it is obtained that $\mathrm{t}$ count $>\mathrm{t}$-table with a significance level of 0.05 . This proves that specialization information services based on psychological data affect increasing student's self-understanding of the choice of majors through Lesson Study for Public Middle School students in Singaraja City.
\end{abstract}

Keywords: specialization, self-understanding, lesson study

\section{INTRODUCTION}

Education aims to develop the potential of students to become human beings who believe and fear God Almighty, have noble character, are healthy, knowledgeable, capable, creative, independent, and become democratic and responsible citizens [1]. Furthermore, national education functions to develop capabilities and shape dignified national character and civilization in order to educate the Nation's Life (Law of the Republic of Indonesia Number 20 of 2003 concerning National Education System, articles 2 and 3) [2]. Moreover, the emphasis is focused on the implementation of the 2013 curriculum, that the counseling services in the school are required by specialization counseling [3]. In this regard, various efforts need to be prepared both through empirical findings and a theoretical framework to support the implementation of specialization services for junior high school children. To achieve quality, it turns out that not every education unit can do it. Examples found in some schools, it turns out that information service specialization in schools has not been fully applied to students. So that many students do not understand their own potential. This of course can reduce the quality of graduates from the school. Many factors become obstacles and obstacles so that they are unable to do so. Based on observations, one reason is because the culture of quality assurance in education units is relatively very weak [4]. Operationally, if you want to foster a culture of quality assurance in each education unit, it is deemed necessary to provide more detailed quality guidance or achievement guidelines, which are based on achieving each component of the National Education Standards.

Schools are parties that make the biggest contribution to the process and results of improving the quality of education, while the community, education providers, and local governments provide facilities in achieving educational quality. Therefore, schools need to be empowered and supported in their efforts to create a quality culture [5]. The community needs to be encouraged to actively support the school program [6]. The regional government needs to increase its coordination efforts so that they develop quality assurance programs and budgeting as their main priority. The needs of people live, and the advancement of science and technology gives rise to increasingly complex social differentiation [7], especially junior high-school students will be faced with a variety of possibilities for important life choices, such as the choice to continue their studies, choices about the world of work, choices about jobs that match their abilities, talents and interests, and all of this require independence in dropping their choices [8].

Problems with specialization or majors in high school are the future career problems of students [9]. Current activities will color one's future. In order for junior highschool students to prepare their future well, students must be provided with a number of specialization information that they will choose when they are in first grade of high school. Because when they entered high school, they were not socialized anymore about the selection of majors, but they had been straightforward as soon as they began studying in class 1 . Besides that in the Era of Industrial Revolution 4.0 was an era that prioritized technological trends with great sophistication. This is also very influential in the field of education. Industrial Revolution 4.0 requires students to have 21 st-century skills, namely understanding and being able to use technology and communication well. The community is required to have skills such as 1) technology literacy; 2) can communicate effectively; 3) able to think critically; 4) can solve problems; and 5) can collaborate. If it is associated with self-understanding, then it has a strong connection. With students having self-awareness of the use of technology today, it will be easier for students to be able to find out about what departments are in school. By utilizing these 
technology students has been able to gather information about the advantages and disadvantages of each existing department. This can be adjusted to the potential of yourself with the direction he will choose later. Therefore, junior high-school students are very relevant if they are provided with sufficient and appropriate information about themselves. This is an asset for the individual concerned to understand the factors that exist in him, the strength factor and the weaknesses. According to John Hayes and Barrie Hopson career information is information that supports the development of the field of work, and based on that information allows one to conduct testing of conformity with his concept [10]. Furthermore, said information specialization is not just a factual object, but as the ability of the psychological process to transform information that is associated with the choices and goals of future life. Selfunderstanding can be known from the disclosure of selfpotential such as: intelligence, interests, talents, personalities, values and attitudes, and other abilities [11]. Therefore, students really need a good self-understanding to be able to adjust their abilities to the demands of future work needs.

Based on the results of interviews conducted by the author of several students at Singaraja City Middle School, they stated that they did not have an interest in the field of study / department with certainty, including also not thinking about their future or the direction of their career. This is possible because of the lack of experiences that can reflect opinions, attitudes, and actions with reality. In addition, many students do not develop their potential.

There is an image, that after completing education it must be difficult to find work, causing a lack of reasonable learning motivation [12]. It is assumed by many parties, especially students, that employment opportunities can only be obtained from connections or other ways that are not / less reasonable. This happens; there is a possibility that students are not well informed about careers in schools related to the industry today. In contrast to the expectations of the teachers at school, their expectations are not in accordance with the facts. Because the gap seems relevant, it will be implemented in a collaborative study with BK teachers to help provide an understanding of information service's specialization to the field of study / department to students so that with information information that students can understand themselves, namely a deeper introduction to self-potential, his own strengths and weaknesses.

According to Santrock self-understanding (selfunderstanding) is a cognitive picture of adolescents about themselves, the basis, and content of adolescent selfconcept [13]. In line with Maslow's opinion, Maslow called personal meaning that describes meaning experienced from self-actualization, individuals who are motivated to know the reason or purpose of their existence [14][15]. He also said that everyone had the urge to fulfill his needs from simple to complex needs. Self-actualization is the achievement of the greatest potential in oneself, being the best he can do, and achieving his life goals [16]. In addition, Baumeister said that meaning contained several interrelated parts of belief between objects, events and relationships [17]. Baumeister emphasizes that meaning ultimately gives direction, intention to everyone, where behavior becomes purposeful, rather than just behaving based on instinct or impulse [18].

According to Hartono, the self-understanding of junior high-school students is a deep introduction to their potential that includes the realm of interest, ability, personality, values and attitudes in which students' recognition of their own personality covers two sides, namely student recognition of excellence and student recognition of their own shortcomings [19]. Strength is a set of abilities that students have both potential and actual. Students' strengths illustrate excellence, students' personal excellence, while students' shortcomings are a number of limitations that students have. The shortage of students illustrates the students' inability which is a barrier for students to achieve their goals.

Based on the description above, it can be concluded that self-understanding is a situation experienced by individuals where someone knows about their potential both physical potential and psychological potential so that individuals understand the direction and purpose of their lives or ideals. Physical potential is a number of abilities that exist in the limbs and the senses of the individual while the individual's psychological potential includes interests, abilities, personality, values and attitudes. The understanding intended here is not only limited to the introduction of students to their superiority but also includes the swallowing of students for deficiencies that exist within themselves.

Based on the definition above, constructs of selfunderstanding can be formulated as follows: students' selfunderstanding is a person's ability to recognize their own potential, which consists of physical potential and psychological potential. Physical potential is the excess in the limbs, the five senses and their strength / quality, while the psychic potential that is all the abilities and strengths possessed by someone related to mental abilities includes: intellectual (IQ), talents, interests, and traits, personality traits.

Psychological information-based specialization service is to provide information about the potential of the students themselves. The direction of student interest in the field of study / department becomes the focus of service in the 2013 curriculum. Related to this, psychological data-based specialization information will be very helpful to know the extent of the abilities possessed by a student along with what talents and interests the students have. Some of the psychological data in question are intelligence, talent, interests, and personality. Information services can be organized through various ways such as lectures, question and answer, and subsequent discussions can be supplemented by demonstrations, leaflets, photo shows, films, videos, and a review of the places or objects in question.

This specialization information service is provided through the lesson study setting. Lesson study is a coaching to improve the service-delivery process (if in Counseling Guidance) which is carried out through collaboration with several teachers who are sustainable and begin with planning, implementing, observing, and reporting on the results of service delivery. As this databased psychology specialization information service that researchers together with state junior high school BK teachers in Singaraja collaborate to carry out service delivery through lesson study settings.

Based on the study above, this study focuses more on psychological information-based information services to improve students' self-understanding. The guidance program carried out by school counselors includes four fields, including; personal, social, career, and learning guidance. To realize the purpose of guidance in schools, 
counselors need to carry out various assistance service activities where one of them is information services. Psychological data includes the potential of students who consists of abilities / abilities, affections / emotions, as well as personality traits, and skills. Ability potential (potential ability) includes: (1) Intelligence / IQ, (2) Talent. The potential of actual (actual ability) includes: Learning outcomes / learning achievement (both formative and summative). Other personality potentials are traits and interests.

\section{MethOD}

This type of research is Quasi Experiment. Karlinger divided the experimental research design into two groups, namely general experimental design and factorial design. [20]. The general experimental design is called a simple random subject design, characterized by randomization. Factorial design is a research structure in which two independent variables or more mutually confronted to examine the effects of the independent and interactive one or more. In this study, the experimental design form used was Nonequivalent Pre-posttest Control Group Design.

The total population in this study grade IX students in two Singaraja City Middle School as many as 983 people. In taking samples, the technique used in this study is a simple random sampling technique. Sampling is done simply by the random method. Simple is meant is direct sampling to individuals / cases and done randomly [21].

The preparations of aspects and indicators of selfunderstanding in this study are: 1) Internal aspect which consists of several indicators as follows: (a) understanding general basic abilities (IQ), (b) understanding basic special abilities (talent), (c) understanding interests, (d) able to understand personality. 2) External aspects consisting of several indicators as follows: (a) Knowing the state of the school to be chosen, (b) Being able to plan for the future or career, (c) Being able to plan steps in determining a career.

Data collection methods used to determine students' self-understanding in this study were questionnaires Questionnaire for self-understanding of specialization with majors using a Likert Scale. Before proper instruments are used to collect data, the research instruments need to be tested for validity. A good instrument is an instrument that meets at least valid and reliability requirements. In applying this instrument, validity and reliability tests is needed. In the content validity test, expert judges is needed to assess the feasibility of the instrument. Based on CVI calculations it can be concluded that the selfunderstanding questionnaire meets good requirements. Based on the validity test of the items on the questionnaire self-understanding of the whole item, namely a number of 10 items declared valid. Then proceed with the reliability test using the Cronbach Alpha formula. Then the reliability coefficient is generated at 0.70 , so it is declared reliable and is in the high category. This is based on the reason that: a) all indicators have been measured, which are displayed in accordance with the valid items a number of 10 items, b) have met the reliability requirements with a reliability coefficient of 0.70 .

In this study, the normality test was carried out by the Kolmogorov-Smirrnov test with the help of SPSS 16.0 for Windows. It is known that the significance level is greater than 0.05 ( $>>0.05)$. Then the variance homogeneity was tested using Levene's Test of Equality of Error Variance. The result of the Lavene statistic is 0.153 with a significance value of 0.696 . As determined with a significance level of $5 \%$, the value is greater than 0.05 .
Furthermore, the hypothesis test conducted in this study uses t-test analysis, because this research is a study comparing one independent variable and one dependent variable whose data is an interval.

\section{RESULTS AND DISCUSSION}

The formulation of the hypothesis in this study is that there are differences in the influence of psychological data-based specialization information services to improve students' self-understanding of departmental choices through the lesson study setting. The results of hypothesis testing are outlined in table 1 as follows:

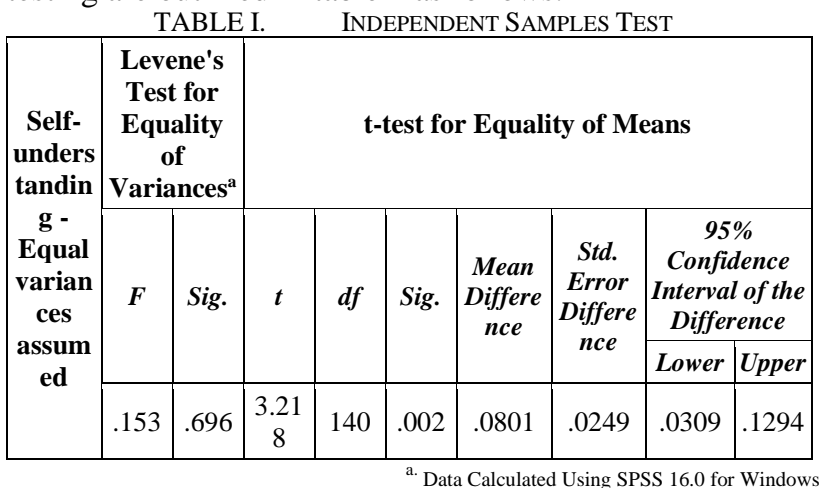

Based on the value of $t$ in table 1 above, it is obtained $\mathrm{t}$-count of 3.218 with $\mathrm{df}=(\mathrm{N}-1)+(\mathrm{N}-1)=(142-1)+(142-$ 1) $=140$ and significance level of $5 \%$. t-table is 1.977 because the t-count is greater than t-table, then $\mathrm{H}_{0}$ is rejected and $\mathrm{H}_{\mathrm{a}}$ is accepted. This proves that the hypothesis in this study is acceptable and means there are differences in the influence of a psychological data-based information service to increase students' selfunderstanding of choice's majors through lesson study settings for Public Middle School Students in Singaraja City

This specialization information service is provided through the lesson study setting. Lesson study is a coaching to improve the service-delivery process (if in Counseling Guidance) which is carried out through collaboration with several teachers who are sustainable and begin with planning, implementing, observing, and reporting on the results of service delivery.

After the provision of psychological data-based information services through the lesson study settings, it can be seen that the influence of the services provided. These changes can be seen from the increase in students' understanding of their condition starting from their intelligence, talents, interests, and personality. Students have been able to know the potential, weaknesses, and strengths that are in themselves to be able to make them into consideration in choosing a future department or career. Through self-understanding, students are able to choose a department that is tailored to their interests, talents, and potential. Self-understanding in the selection of important majors is given since students sit in junior high school because when they enter high school, they are no longer socialized about the selection of majors, but they have been straight-forwarded as soon as they start studying in class 1 . Very relevant if provided with sufficient and appropriate information about him, this will be an asset for the individual concerned to understand the factors that exist in him, the strength factor and the weaknesses.

The results of this study have implications for: (1) counseling teachers in providing counseling services 
namely counselors to be able to plan and implement a process of guidance and counseling services in a more creative and innovative way to stimulate counselees to be better able to understand their situation and choose majors in accordance with their potential, interests, and talents that exist in him, (2) planning and developing a counseling model that requires that these services be appropriately applied in schools. This counseling service provides new innovations in its implementation because it is done with the lesson study setting. This shows the progress of the implementation of guidance and counseling services in helping students understand every potential that exists within themselves and can help counselees in organizing, monitoring, and evaluating themselves in achieving behavioral change in a better direction.

\section{Conclusion}

Based on the results of the analysis and discussion of the research that has been conducted, the results show that specialization information services are based on influential psychological data to improve students' self-understanding of the choice of departmental choices through lesson study settings for Public Middle School Students in Singaraja City. This result can be seen based on the value of t-count (3.218) > t-table (1.977), and the significance level of 5\% then $\mathrm{H}_{0}$ are rejected, and $\mathrm{H}_{\mathrm{a}}$ is accepted.

\section{REFERENCES}

[1] Y. dan M. N. Novitasari, "Bimbingan dan Konseling Pelajar (Akademik) dalam Perspektif Islam," J. Educ. Couns., vol. 1, pp. 53-78, 2017.

[2] Undang-undang Republik Indonesia, "Sistem Pendidikan Nasional." 2003.

[3] A. Wibowo, Manajemen Pendidikan Karakter di Sekolah. Pustaka Pelajar, 2017

[4] S. Giarti and S. Astuti, "Implementasi TQM Melalui Pelatihan Model in House Training untuk Meningkatkan Kompetensi Pedagogik Guru SD," Sch. J. Pendidik. Dan Kebud., vol. 6, no. 2 , pp. 80-91, 2016.

[5] N. N. Sukerti, N. Dantes, and N. K. Suarni, "Kontribusi Pola Kepemimpinan Kepala Sekolah, Iklim Sekolah, dan Manajemen Mutu Berbasis Sekolah (MMBS) Terhadap Kinerja Guru Pada
Gugus II Kuta Utara,” PENDASI J. Pendidik. Dasar Indones., vol. 4, no. 1,2015

[6] M. Ali, "Implementasi Model Manajemen Berbasis Sekolah (MBS) di SMA Negeri 2 Unggulan Daerah Sangatta Utara," Syamil, vol. 3, no. 2, pp. 303-338, 2015.

[7] S. A. \& H. N. Tumanggor, R., Kholis Ridlo, Ilmu Sosial dan Budaya Dasar. Kencana, 2017.

[8] S. Syafaruddin, "Implementasi manajemen bimbingan konseling di MAN Binjai,", 2015.

[9] R. Mardiyati, B. D., \& Yuniawati, "Perbedaan Adaptabilitas Karir Ditinjau Dari Jenis Sekolah (SMA dan SMK)," EMPATHY J. Fak. Psikol., vol. 3, no. 1, pp. 31-41, 2015.

[10] B. Hopson and J. Hayes, The Theory and Practice of Vocational Guidance: A Selection of Readings. Elsevier, 2014

[11] I. N. B. Saputra, N. Dantes, and L. P. S. Lestari, "Penerapan Layanan Informasi Berbasis Teori Trait And Factor Untuk Meningkatkan Pemahaman Diri dalam Pilihan Karir Siswa Kelas XI IPA 1 SMA N 1 Seririt Tahun Ajaran 2014/2015," J. Ilm. Bimbing. Konseling Undiksha, vol. 3, no. 1, 2015.

[12] J. Hayes, "Efektivitas Teori Karier Holland Melalui Layanan Informasi Untuk Meningkatkan Pemahaman Diri Terhadap Kesiapan Kerja Siswa," J. Ilm. Bimbing. Konseling, vol. 1, 2014.

[13] J. W. Santrock, Psikologi Pendidikan Edisi Kedua. Kencana Prenada Media Group, 2007

[14] K. Galek, K. J. Flannelly, C. G. Ellison, and K. R. B. Jankowski, "Religion, Meaning and Purpose, and Mental Health," Psycholog. Relig. Spiritual., vol. 7, no. 1, pp. 1-12, 2015

[15] R. Jesse and R. R. Griffi, "Psilocybin Research At Johns Hopkins A 2014 Report," Seek. sacred with Psychoact. Subst. Chem. paths to Spiritual. to god, vol. 2, no. 1, pp. 29-43, 2014.

[16] W. Desriana, A., Waluyo, H. D., \& Widayanto, "Pengaruh Budaya Organisasi, Aktualisasi Diri, dan Penghargaan terhadap Prestasi Kerja Karyawan PT. Kereta Api Indonesia (Persero) DAOP IV Semarang," J. Soc. Polit. Sci., vol. 4, no. 1, pp. 1-9, 2014.

[17] M. J. MacKenzie and R. F. Baumeister, "Meaning in Life: Nature, Needs, and Myths," in Meaning in positive and existential psychology, New York: Springer, 2014, pp. 25-37.

[18] R. Yulia, A., Dahlan, S., \& Widiastuti, "The Use of IEKAD (Inventori Eksplorasi Karir Arahan Diri) to Help Improve Students Vocational Self Understanding," ALIBKIN (Jurnal Bimbing. Konseling), vol. 5, no. 4, 2017.

[19] Hartono, Bimbingan Karier Berbantuan Komputer Untuk Siswa SMA. Surabaya: UNIPA University Press, 2010

[20] F. N. Kerlinger, Foundations of Behavioral Research. San Diego: CA: Harcourt College Publishers, 2000.

[21] N. Dantes, Metode Penelitian. Yogyakarta: ANDI, 2014. 